\title{
Journalistisk dækning af danske shitstorme: Genmæle, vidensbidrag og kildekontakt
}

\author{
EMIL OLSEN \\ Roskilde Universitet \\ NICKLAS ANDERSEN \\ Roskilde Universitet \\ IDA ZACHRAU \\ Roskilde Universitet
}

\section{Abstract}

I denne artikel undersøger vi, hvordan danske journalister dækker det relativt nye, online mediefænomen 'shitstorme.' Vi argumenterer først for, at shitstorme er et biprodukt af negativ electronic word-ofmouth på sociale medier, og at shitstorme skal forstås i sammenhæng med allerede eksisterende studier af medieskandaler. Herefter etablerer vi en analyseramme til vores indholdsanalyse ud fra en række journalistiske idealer, som vi mener, at de fleste professionelle journalister bør kunne tilslutte sig - at journalister bør lytte til og give den anklagede part mulighed for genmæle, forsøge at tilføje nye og eksklusive kilder og perspektiver til deres historier og verificere og faktatjekke informationer. Vores empiri er indsamlet via Infomedia og består af $i$ alt 1.107 artikler, der omhandler 10 shitstorme fra 2019. Vi kan ud fra vores analyse konkludere, at de fleste journalister lader den anklagede part komme til genmæle, og at journalisterne også forsøger at tilføje eksklusive og nye kilder og perspektiver til deres historier. Ydermere kan vi konkludere, at shitstorme, hvor kritikken er rettet mod politiske aktører, i højere grad motiverer kildekontakt. 
Med afsæt i de analytiske konklusioner diskuterer vi afslutningsvis idealernes relevans i dækningen af shitstorme.

\section{NØGLEORD}

Shitstorm, medieskandaler, journalistiske idealer, sociale medier, electronic word-of-mouth (eWOM)

\section{Indledning}

I de senere år har journalister i stigende grad lavet journalistiske historier om brugere på sociale medier, der samler sig, udskælder og udskammer én, der udtaler sig eller mener noget, der af majoriteten opfattes som et brud på gængse normer eller lovmæssigheder (Pfeffer m.fl. 2014: 118) - i folkemunde kaldet shitstorme. Fra 2009 til 2019 er der sket en syvdobling af journalistiske artikler indeholdende ordet "shitstorm" i Danmark1, og Danmarks Radio har siden foråret 2016 også sendt radioprogrammet Shitstorm på $P 1$.

At journalister orienterer sig mod online mediesfærer for at finde inspiration til historier og kildebrug, giver i og for sig mening. Majoriteten af danskerne har nemlig deres daglige gang på sociale medier (Linaa Jensen 2020), og Facebook og andre sociale medieplatforme er blevet centrale research- og distributionsarenaer for danske mediehuse (Hammarlin 2019: 12, Skovsgaard 2018) med deres direkte adgang til danskernes hverdagssamtaler, bekymringer og interesser. Globalt set eksisterer der et enormt mobiliseringspotentiale i sociale medieplatforme, og journalistisk dækning af alt fra Det Arabiske Forår, hashtagget \#MeToo og Black Lives Matter-bevægelsen ville være svært uden inddragelse af sociale medier i et eller andet omfang (Hammarlin 2019: 12).

Men shitstormen og nyheden eksisterer ikke i et ligeværdigt forhold: I det øjeblik shitstormen kommer under redaktionel behandling, rykkes der ved dens naturlige habitat. Denne forskningsartikel belyser gennem en kvantitativ indholdsanalyse af 10 shitstorme fra 2019, hvad der sker, når journalister 'blander sig' i shitstorme. Vi vil undersøge og diskutere journalistisk dækning af 10 danske shitstorme ud fra tre hovedspørgsmål: I hvor høj grad får journalister indhentet 
genmæle fra anklagede parter; i hvor grad inddrages nye vidensbidrag i dækningen; og i hvor høj grad kontakter journalister kilder citeret fra sociale medier.

For at forstå problematiseringen af en arbejdsgang med et relativt nyt onlinefænomen som shitstorme søger vi tilbage mod tidligere studier af skandaler (Thompson 2002, Blach-Ørsten 2011). Fællesnævneren for shitstormen og skandalen er nemlig, at begge eksisterer i kraft af, at 'nogen' har gjort eller sagt noget, der opfattes som moralsk forkasteligt af 'nogle andre' (Thompson 2002: 27, Pfeffer m.fl. 2014: 118). Fra et nyhedsjournalistisk synspunkt vil denne dynamik ofte fordre en opmærksomhed og nysgerrighed, da det udmønter sig i en konkret konflikt med modsatrettede synspunkter - en klassisk nyhedsværdi (Galtung \& Ruge 1965: 68). Men hvor skandaleforskningen slår sig op på, at journalister indtager en helt særegen position i dækningen af disse som en art gatekeeper med særlige midler og mål for at kunne afsløre og afdække magtmisbrug, lovbrud og deslige (Thompson 2002: 72), har journalister som nævnt ikke nødvendigvis samme særegne position i dækningen af shitstorme, da denne onlinekonflikt/skandale i forvejen har cirkuleret på sociale medier. Sagt med andre ord: Shitstormen finder allerede sted. Den har cirkuleret blandt brugere på sociale medier og har dermed et publikum, inden journalister 'blander sig' (Pfeffer m.fl. 2014, Rauschnabel m.fl. 2016, Einwiller m.fl. 2017, Johnen m.fl. 2018).

At shitstorme udspringer af social medieaktivitet udfordrer for det første journalistikken som institution. Når journalister blander sig i shitstorme og begynder at inddrage viden fra kilder på sociale medier, rykker det ikke kun ved shitstormens oprindelige form, men ændrer også den vante måde, som journalistikken normalt bliver beskuet på af de aktører, der omkredser den.

Vi tager afsæt $i$ to anskuelser af shitstormfænomenet og de iboende presseetiske dilemmaer, der ligger i at dække dem journalistisk: På den ene side kan man argumentere for, at shitstormen som fænomen kan indeholde et demokratisk og emancipatorisk potentiale, da det hjælper den "aktive" del af offentligheden med at nå deres "legitime" mål, hvilket fremhæves i tyske studier af shitstorme (Einwiller m.fl. 2017: 1179). Ved hjælp af shitstormen bliver offentligheden givet den mulighed at deltage i en verserende debat per egen indskydelse 
frem for først at skulle passere gennem det redaktionelle nåleøje for nyhedsværdi. Shitstorme afhænger altså af folkedybets engagement i sagen, og derved opnår offentligheden en udvidet mulighed for at sætte dagsordenen og dermed "nå deres legitime mål” (ibid.).

På den anden side risikerer journalister, der skriver om shitstorme, at forstærke kontroversen, så problemerne virker større og mere presserende, end de faktisk er (Einwiller m.fl. 2017: 1179), hvilket kan spejles i forskeres tidligere advarsler mod trivialiserende dækning af mindre forseelser som skandaler (Thompson 2002: 246, Blach-Ørsten 2011) samt diskussionen af homogen og selvrefererende journalistisk dækning i tilfælde af mediestorme (Kepplinger \& Habermeier 1995: 373, Vasterman 2005: 514, Elmelund-Præstekær \& Wien 2007: 33, Boydstun m.fl. 2014: 512). Journalister kan dels få malet et ikke objektivt billede af konfliktens størrelse, dels gøre dækningen så ensartet, at konflikten ikke nuanceres med nye vidensbidrag eller (andre) involverede parter. Så hvordan kan journalistikkens rolle i arbejdet med shitstorme retfærdiggøres, hvis der er en potentiel risiko for, at journalistikken ikke bidrager med mere, end hvad læseren i forvejen er givet på de sociale medier?

Lige præcis derfor er det i forskningsøjemed nødvendigt at granske journalisters kildebrug, når de dækker shitstorme. For den sociale medieaktivitet, som kilderne udøver, sætter mediehuse i (nye) etiske og publicistiske dilemmaer. Dette ser vi særligt to årsager til: I en shitstorm er det altid givet, at "en" - det være sig en person, en virksomhed eller noget helt tredje - bliver kritiseret af "nogle andre" (Pfeffer m.fl. 2014: 118, Einwiller m.fl. 2017: 1181). Den journalistiske dækning af en shitstorm vil altså i princippet altid afstedkomme et idealistisk krav om, at den anklagede part skal høres og have mulighed for genmæle. Det er både et dogme, som journalistikken har levet efter i mange år i henhold til Pressenævnet og medieansvarsloven (Pressenævnet A), men det er også i medieforskningen tidligere blevet anset som et vigtigt element for det at bedrive god og retfærdig journalistik (Kovach \& Rosenstiel 2001: 77f). Men dette ideal i kombination med dækningen af shitstorme - der må siges at være særligt betingede af at cirkulere omkring anklagede parter - er ikke tidligere blevet sammenholdt i dansk medieforskning, hvorfor denne artikel fungerer som et bidrag til at klarlægge den praksis. 
En anden vigtig årsag handler generelt om de kilder, som journalister anvender via sociale medier. Kilden fra sociale medier er betydningsfuld i den forstand, fordi denne i første omgang formulerer den kritik, som shitstormen bliver bragt til live af (Pfeffer m.fl. 2014: 118, Einwiller m.fl. 2017: 1181). Der eksisterer ingen journalistik dækning af shitstorme uden en eller flere kilder fra sociale medier. Selvom nyere rapporter viser, at det er et mindretal af danskerne, der reelt bruger digitale fora til holdningsudveksling (Linaa Jensen 2020), spiller kilden fra sociale medier en helt særlig rolle i forhold til at kunne be- eller afkræfte den historie, som journalisten agter at dække. I Tyskland har man tidligere klarlagt, at mens nogle shitstorme er veldokumenterede og velbegrundede, baserer andre shitstorme sig på det pure opspind og har altså ikke hold i den fremsatte kritik (Pfeffer m.fl. 2014: 118). Netop derfor fordrer brugen af kilder fra sociale medier i dækningen af shitstorme, at journalister i højere grad kontakter dem, taler med dem og faktatjekker deres udsagn for at kunne rejse en retvisende fremstilling af den verserende sag. En arbejdsgang, der generelt ophøjes i Pressenævnets principper om, at journalistikken skal bringe korrekt information (Pressenævnet A) (uagtet om der er tale om dækningen af shitstorme eller andre typer af sager) og en shitstorm-specifik pointe, der tidligere er trukket frem af danske medieforskere (Metier 2018), men som aldrig er blevet aktivt undersøgt empirisk. Dette bidrager denne artikel også med.

Overordnet set skal denne artikel altså ses som et bidrag i undersøgelsen af, hvordan danske journalister dækker shitstorme set i forhold til idealtypiske praksisser omkring genmæle og kildebrug, der har til formål at komme nærmere en forståelse af shitstorme og journalistisk praksis i kombination med hinanden.

Bidraget sker som et supplement til eksisterende litteratur, der undersøger lignende forskningsspørgsmål, men som ikke inddrager spørgsmål om det direkte link mellem shitstorme og presseetik. Man har i europæisk kontekst tidligere undersøgt bredere begreber som mediestorme (Vasterman 2005, Elmelund-Præstekær \& Wien 2007), hvor termer som “triggerartikler" bliver anvendt i unders $\emptyset$ gelsen af, hvordan den journalistiske dækning udvikler sig løbende i intensiv dækning af sager ved at sammenligne den første artikel med de øvrige artikler i en samlet produktionsmængde. Her anvender man ikke data fra sociale medier. Alligevel trækker vi på viden her- 
fra og har blandt andet konceptualiseret kodningskategorien "nye vidensbidrag" i vores kvantitative indholdsanalyse for at afdække, hvordan nyhedsdækningen af en shitstorm udvikler sig i substansen. Vi kan dermed undersøge, hvorvidt journalister faktisk bidrager med nye oplysninger og dermed driver processen fremad, eller om de blot selvrefererer og trivialiserer dækningen (Thompson 2002, Blach-Ørsten 2011, Kepplinger \& Habermeier 1995, Vasterman 2005, Elmelund-Præstekær \& Wien 2007, Boydstun m.fl. 2014).

Man har i nyere tid forsket specifikt i shitstormens væsen og værdi i Tyskland med meget konkret inddragelse af sociale medier (Pfeffer m.fl. 2014, Einwiller m.fl. 2017), mens man ikke finder et sammenligneligt dansk modstykke. Der findes dog et dansk casespecifikt studie, der bidrager til forståelsen af, at shitstorme sker i kraft af sagsorienterede (sub)offentligheder, der har deres færden på de sociale medier (Birkbak 2018), men disse sagsorienterede offentligheder er ikke før blevet undersøgt i et tværsnit af forskellige shitstorme med forskellige aktører, forskellige kritikpunkter og forskellige tematikker fordelt ud over et helt år.

Formålet er altså at ramme et forskningsmæssigt blindt punkt i krydsfeltet mellem presseetik, shitstorme, sociale medier og journalistisk praksis i dansk kontekst. For at indkredse shitstorme som kommunikativt fænomen vil vi inddrage teoretiske perspektiver fra skandale- og mediestormsforskning. Herudover vil vi diskutere de presseetiske implikationer og dilemmaer, der gemmer sig i dækningen af shitstorme. Alt i alt er formålet at vise, hvilke særlige forbehold journalister bør have, når de dækker shitstorme.

\section{Teori: shitstorme, skandaler og mediestorme?}

\section{Hvad er en shitstorm?}

Shitstorme er komplekse og kan principielt ramme samt udløses af alle aktører i samfundet, såfremt de har forbindelse til internettet. En shitstorm opstår, når en del af offentligheden tilkendegiver deres kritik af et opfattet normbrud online (Pfeffer m.fl. 2014: 118). Helt overordnet kan de deles op i to hovedkategorier: dokumenterede og 
udokumenterede, alt efter om handlingen eller hændelsen, der har ansporet en online massereaktion, kan bekræftes eller ej (ibid.). Vi antager, at denne hierarkiske opdeling af shitstorme er yderst relevant for en journalist, der søger at dække dem, da et grundprincip for etisk korrekt og retvisende journalistisk dækning netop er stringent dokumentation af en sags kendsgerninger (Ward 2019: 309ff).

Reaktionen kan tage mange former og spredes mellem diverse sociale medier, da teknologien tillader, at man tager et skærmbillede af den oprindelige (an)klage og deler den mellem onlineplatforme. Samtlige digitale kommunikations- og interaktionsformer i en shitstorm kaldes i international forskning for negativ electronic word-ofmouth, som forkortes eWOM herfra (ibid., Einwiller 2017, Rauschnabel m.fl. 2016, Johnen m.fl. 2018). Massereaktionen, altså eWOM, kommer fra, hvad nogle forskere betegner som en sagsorienteret (sub)offentlighed, når afsenderne har et mål - defineret eller ej - med deres online engagement (Birkbak 2018: 38ff, Einwiller 2017: 1181, Hammarlin 2019). Alle aktører med adgang til internettet kan principielt igangsætte shitstorme; dog kan aktører med store følgerskarer hurtigere mobilisere opmærksomhed omkring en hændelse, ligesom semioffentlige grupper kan koordinere udbrud af eWOM.

\section{Shitstorme, skandaler og traditionelle medier}

I den udvalgte skandalelitteratur er et centralt karakteristikum ved skandalen, at den er uløseligt forbundet med traditionelle journalistiske medier (Thompson 2002, Blach-Ørsten 2011). Som Thompson noterer sig: "Afsløringer og kommentarer udgør grundlaget for skandalen” (ibid.: 72). Kommentarerne er reaktionen på det journalistisk afslørede norm- eller lovbrud. Skandaler såvel som shitstorme er altså betinget af, at nogen misbilliger en (opfattet) handling eller begivenhed.

Vi finder imidlertid en central forskel i de to fænomeners relation til journalistiske medier: Skandaleprocessen begynder ifølge Thompson og Blach-Ørsten typisk med en såkaldt præskandale (en moralsk overtrædelse) - men bliver først til en egentlig skandale, efter den moralske overtrædelse er blevet medieret i form af journalistiske publikationer (afsløringer), og disse har affødt en negativ reaktion fra den brede offentlighed (kommentarer) (Thompson 2002: 83ff, BlachØrsten 2011: 9f). I et skandaleforløb er offentlighedens reaktion altså 
performativt afhængig af, at journalister - i kraft af deres rolle som undersøgere og formidlere - giver skandalesnebolden det første skub. I en shitstorm er den (sub)offentlige misbilligelse udelukkende performativt betinget af misbilligelsen selv - altså den negative eWOM. Her er afsløringen og kommentarerne altså smeltet sammen i forløbets første led, da det typisk er en forurettet part, der beretter om en angivelig hændelse, fordi den opfattes som moralsk forkastelig (Pfeffer m.fl. 2014: 120ff, Einwiller m.fl. 2017: 1180ff). Traditionelle medier kan agere megafon og/eller filter for shitstorme ved at dække dem og eksempelvis formidle, om de er underbygget af dokumentation eller ej. Det centrale dilemma er, at traditionel mediedækning af en angivelig shitstorm vil sprede og potentielt forstærke shitstormen (Pfeffer m.fl. 2014: 119f, Einwiller m.fl. 2017: 1178). Traditionelle medier spiller en "nøglerolle" i spredningen af onlinestorme af to årsager: Dels legitimerer det (sub)offentlighedens sag, at den bliver publiceret af et etableret medie. Dels vil eksponering i et nyhedsmedie øge antallet af personer, der kender til shitstormen.

\section{Shitstorme og mediestorme}

Fælles for shitstorme og skandaler er, at mediedækningen af dem kan være intens, gribe om sig og danne et såkaldt selvrefererende system. Dette er en veldokumenteret journalistisk tendens, der opstår, når bestemte hændelser dominerer mediedagsordenen i en afgrænset tidsperiode - altså såkaldte mediestorme. Medier vil i sådanne storme overvåge, kopiere og citere hinandens dagsordener, vinkler og kilder, hvilket typisk vil homogenisere dækningen (Kepplinger \& Habermeier 1995: 373, Vasterman 2005: 514, Elmelund-Præstekær \& Wien 2007: 33, Boydstun m.fl. 2014: 512). Men dækningen opstår ikke ud af ingenting. Man opererer inden for litteraturen om mediestorme med begrebet triggerartikel. I et skandaleforløb vil triggerartiklen således være den først publicerede artikel, som ét medie står for, der afslører en moralsk forkastelig hændelse, hvorefter andre medier begynder at referere tilbage hertil i deres egne artikler om sagen.

En antagelse, vi tager med herfra, er, at traditionelle medier kan ændre deres nyhedsværdier i perioder med mediestorme - hvor man prioriterer at bruge ressourcer på at ride med på nyhedsbølgen i mediestormen og dermed nedprioritere eksklusivitet og dagsorden- 
sættelse, som normalt er væsentlige for nyhedsmedier (Willig 2011: 165ff, Lund 2000).

\section{Presseetik, shitstorme og samfundet: praksis og teori}

Denne artikel skal belyse presseetiske dilemmaer i dækningen af shitstorme. Etik kan imidlertid være mange ting, så vi vil konkretisere, hvilke etiske grundantagelser vi analyserer ud fra.

\section{Shitstorme og genmæle}

Vores forståelse af presseetik i denne sammenhæng tager dels udgangspunkt i Pressenævnets vejledende regler for god presseskik, dels i teori om presseetik. Størstedelen af danske medier er medlem af Pressenævnet og derfor underlagt medieansvarsloven. En grundpille i regelsættet er, at man i tilfælde af kritik mod navngivne personer eller entiteter skal give denne eller disse muligheder for genmæle (Pressenævnet A). At anklagede parter bør høres for genmæle er desuden et centralt element i etiske teorier om journalistik (Kovach \& Rosenstiel 2001: 77f). Anklagerne i en shitstorm kan have ødelæggende konsekvenser for de indblandede parter, og derfor synes kravet om genmæle at være væsentligt.

Shitstormen mod Jensens Bøfhus i 2014, hvor restaurantkæden havde vundet en sag om misbrug af brandnavn mod Jensens Fiskerestaurant i Sæby, er et godt eksempel på en massereaktion, der via sociale medier formåede at påvirke virksomhedens bundlinje negativt. I virksomhedens årsrapport 2015 står der blandt andet, at "en uventet kraftig og negativ mediestorm [...] medførte en betydelig reduktion i antallet af gæster" på omkring 25 pct. (Jensens Bøfhus, årsrapport 2015). Dette afspejles i marketingslitteratur, hvor shitstorme betegnes som "collective brand attacks" (Rauschnabel m.fl. 2016: 381ff), mens andre i krisekommunikationsfeltet argumenterer for, at det er essentielt for virksomheder at være strategisk forberedte på shitstorme og at kunne forebygge og/eller afbøde dem (Herhausen m.fl. 2019). Vi antager, at journalister, der skriver om shitstorme, bærer et ansvar for, at anklagede parter får lov til at give svar på kritik. 
Derfor vil vi undersøge, i hvor høj grad danske journalister faktisk får anklagede (shitstorms)parter i tale.

\section{Shitstorme og retvisende repræsentation af virkeligheden}

Vi trækker som nævnt også på forskningslitteratur om journalistisk etik. Herunder ser vi Stephen Wards arbejde som særligt relevant i forhold til shitstorme (Ward 2019: 311). Han fokuserer på journalisternes sociale ansvar, når de vinkler og formidler nyheder. Medierne skal ifølge Ward give borgerne i samfundet en retvisende repræsentation af virkeligheden - præcis samme hensyn findes i Pressenævnets retningslinjer for danske journalister (Pressenævnet A). I forlængelse af idealet om tilstræbt objektivitet argumenteres der for, at journalistikkens primære formål bør være at forsyne samfundet med et forum for udvekslingen af meninger og holdninger (ibid.: 311f). Skandaler kan i et funktionalistisk lys ses som "kollektive syndsforladelsesritualer" (Thompson 2001: 243), og det samme kan shitstorme - især hvis man forstår dem som udført og udløst af "sagsorienterede offentligheder" (Birkbak 2018: 37f) og ikke en samling personer, der tilfældigvis har set og kommenteret et opslag på et socialt medie. I denne læsning kan man se shitstorme som konkretiseringer af større abstrakte debatter i samfundet. Dermed antager vi, at det kan være samfundsrelevant samt journalistisk og presseetisk forsvarligt at dække shitstorme, idet de kan bruges som tematiseringer af samfundsrelevante debatter. En udfordring for journalisterne er dog, selv i denne funktionalistiske forståelse af shitstorme, at udvælge, hvilke af de mange udbrud af negativ eWOM, der konstant bliver kommunikeret om på sociale medier, de vil dække. Godt fire millioner danskere logger dagligt på sociale medier - selv hvis kun 1 promille af dem skrev kommentarer og opslag, ville det give over 4.000 gange eWOM om dagen (Danmarks Statistik 2020).

Risikoen er, at journalisterne i deres historier kan vælge at fremhæve de mest markante udtalelser fra enten interviewpersoner eller brugere i kommentarfelterne. I den afsluttende diskussion vil vi eksemplificere denne praksis i relation til shitstorme. Vi antager, at der også med hensyn til det presseetiske ideal om korrekt repræsentation kan opstå diskrepanser mellem idealisme og praksis. Denne diskrepans kan antagelig blive forstærket af de nævnte tendenser i tilfælde af mediestorme, altså når et bredt udsnit af medierne skriver 
om den samme sag baseret på de samme kilder og angivelige kendsgerninger. Hvis et journalistisk medie fremhæver den mest sensationelle eWOM, er det sandsynligt, at et konkurrerende medie vil bruge de samme citater og/eller vil anvende samme vinkling. Samfundsdebatten og det kollektive syndsforladelsesritual, som shitstorme teoretisk set kan lægge op til, kan altså komme til at udspille sig på et forvrænget grundlag, hvis journalister ikke er stringente ift. presseetiske principper.

\section{Shitstorme og korrekt bearbejdning af kilder og materiale}

Vigtigheden af genmæle og korrekt repræsentation kan yderligere udledes af journalistiske principper for korrekt bearbejdning af kilder og materiale: Ward beskriver, hvordan journalistiske arbejdsnormer og regelsæt tager afsæt i koncepter om objektivitet, nøjagtighed og verifikation (Ward 2019: 309). Disse koncepter reducerer vi til spørgsmål om genmæle, korrekt repræsentation og verifikation af kilder. For hvis det journalistiske arbejde ideelt set bør tilstræbe objektivitet, må genmæle altid eftersøges, da præsentationen af blot én side af en nyhedshistorie teoretisk set må være mindre objektiv og nøjagtig end at præsentere flere sider. Fra normerne kan man yderligere udlede, at man gennem god kildebrug kan imødekomme princippet om verifikation: Når journalisten tager kontakt til kilderne, vil påstandene alt andet lige være bedre verificeret, end hvis journalisten ikke tager kontakt til kilden.

\section{Operationaliseringen af teoretiske begreber}

Vi ved, at der ofte er involveret kilder fra sociale medier i shitstorme (Pfeffer m.fl. 2014, Einwiller m.fl. 2017, Paulussen \& Harder 2014), og vi har derfor valgt at undersøge, hvor mange kilder fra sociale medier der involveres, og hvem disse kilder er. Begrebet spiller en særlig vigtig rolle i andet og tredje analyseafsnit, som beskæftiger sig med kilder fra sociale medier og journalisters anvendelse af sociale medier som kilde til oplysninger.

Fra litteraturen om mediestorme (Kepplinger \& Habermeier 1995, Vasterman 2005, Elmelund-Præstekær \& Wien 2007, Boydstun m.fl. 2014) trækker vi på begrebet triggerartikel, der kort sagt beskriver den første artikel i en shitstorm. På baggrund af mediestormsteori- 
ens andet begreb om selvreferentialitet er det yderligere interessant at undersøge, hvorvidt journalister i en given shitstorm tilbyder læserne nye oplysninger i sagen - altså om de bringer eksklusive vidensbidrag (se også Willig 2011: 191). Derfor har vi operationaliseret eksklusivitetskriteriet som journalisters "nye vidensbidrag" $\mathrm{i}$ forhold til den lokaliserede triggerartikel. Når en artikel citerer en kilde, og dennes udtalelser ikke indgår i triggerartiklen for en case, betragtes det som et nyt vidensbidrag. Vi funderer desuden vores analyse i presseetikken ved at holde vores resultater op mod Pressenævnets vejledende idealer om genmoele og god presseskik (Pressenævnet A, Pressenævnet B), hvilket vi relaterer til presseetiske perspektiver fra medieforskningen (Kovach \& Rosenstiel 2001: 77f, Ward 2019). Disse idealer har vi omsat til indholdsanalytiske kodningskategorier - altså genmoele, nye vidensbidrag og eWOM.

\section{Metode}

I analysen præsenterer vi resultaterne af en kvantitativ indholdsanalyse af 10 danske nyhedsdækninger af shitstorme bestående af i alt 1.107 artikler udgivet i perioden 19. februar 2019 til 26. december 2019 fundet via søgedatabasen Infomedia.

\section{Dataindsamling}

For at sikre, at en samling af artikler omhandlende et givent emne faktisk var del af en shitstorm, har vi formuleret en række krav til, hvad der i vores undersøgelse udgør en shitstorm:

Først og fremmest skulle dækningen indeholde ytringer fra sociale medier (eWOM). Derfor blev et af søgekriterierne for lokalisering af shitstorme, at de som minimum skulle inkludere ordene "sociale medier". Dette kombinerede vi yderligere med søgeordene "shitstorm", "medie storm" eller "storm" for at frasortere de mange ikkerelaterede artikler, der indeholder ordene "sociale medier". Søgestrengen i Infomedia så således ud: "shitstorm" OR "mediestorm" OR "storm" AND "sociale medier". Derudover afgrænsede vi yderligere med udgangspunkt i Thompsons (2002) teoretisering af skandaler og Einwiller m.fl.'s (2017) undersøgelse af tyske mediers dækning af shitstorme - at triggerartiklen skulle italesætte et (opfattet) normbrud. 
Herefter blev perioden for undersøgelsen indskrænket til 2019, og vi fik herved 90 cases. Disse dækninger varierede i størrelse fra fem artikler i alt til over 500. Vi frasorterede alle dækninger, der indeholdt færre end 10 artikler ud fra en antagelse om, at denne slags dækninger ikke er intensive nok til at udgøre en egentlig shitstorm, hvilket efterlod os med 49 unikke dækninger. For at få et nuanceret billede var vi opmærksomme på, at dækningerne ikke skulle omhandle de samme mennesker, samme tematiske problemstillinger og ikke foregå på samme tid af året. Med disse krav in mente inddelte vi de 49 dækninger i kronologisk rækkefølge og udvalgte derefter 10 cases, som kan ses i tabel 1:

\begin{tabular}{|l|c|c|c|}
\hline Case - Dette udløste shitstormene & Tidsspænd & $\begin{array}{c}\text { Antal relevante } \\
\text { artikler }\end{array}$ & $\begin{array}{c}\text { Antal unikke } \\
\text { artikler }\end{array}$ \\
\hline $\begin{array}{l}\text { Føtex-medarbejder fyret for at spise } \\
\text { kanelsnegl. }\end{array}$ & $19 / 02-26 / 02$ & 153 & 78 \\
\hline $\begin{array}{l}\text { Politiker Simon Simonsen skriver } \\
\text { opslag om Joy Mogensens graviditet. }\end{array}$ & $30 / 04-20 / 05$ & 234 & 46 \\
\hline $\begin{array}{l}\text { Politiker Stig Grenov skriver tweet om } \\
\text { abort. }\end{array}$ & $23 / 05-11 / 06$ & 143 & 9 \\
\hline $\begin{array}{l}\text { Kræftsyge Hilde-Kristin Reed Mogen- } \\
\text { sen kritiserer Ringkøbing-Skjern } \\
\text { Kommune. }\end{array}$ & $30 / 05-21 / 06$ & 102 & 95 \\
\hline $\begin{array}{l}\text { Fodboldspiller Joakim Mæhle klager } \\
\text { over manglende spilletid. }\end{array}$ & $18 / 06-22 / 06$ & 140 & 24 \\
\hline $\begin{array}{l}\text { Sagsbehandlere i Helsingør Kommune } \\
\text { får isbarkonkurrence for at nedbringe } \\
\text { antallet af sygedagpengemodtagere. }\end{array}$ & $01 / 07-18 / 07$ & 99 & 33 \\
\hline Restaurant vil sælge foie gras. & $24 / 09-07 / 10$ & 40 & 36 \\
\hline $\begin{array}{l}\text { IKEA lancerer vinterkollektion og } \\
\text { kalder den Vinterfest. }\end{array}$ & $29 / 10-23 / 12$ & 136 & 35 \\
\hline $\begin{array}{l}\text { POWER anklages for at snyde kunder } \\
\text { med Black Friday-tilbud. }\end{array}$ & $27 / 11$ - 28/11 & 14 & 14 \\
\hline $\begin{array}{l}\text { Ford-forhandlere har for få gratis nis- } \\
\text { sehuer at uddele til fremmødte børn. }\end{array}$ & $15 / 12$ - 26/12 & 46 & 40 \\
\hline
\end{tabular}

Tabel 1: Oversigt over forskellige cases i analysen

Ved indsamling af empiri blev vi opmærksomme på, at mange af de samme Ritzau-telegrammer gik igen i både lokale og nationale medier. I selve analysearbejdet har vi derfor frasorteret alle artikler med samme indhold i forsøget på at undgå analyse af gengangere. Det efterlod os med i alt 410 unikke artikler fordelt over de 10 cases. Der vil i analysen blive henvist til empiri med forskellig N, hvilket skyl- 
des, at vores kodningskategorier ikke altid har gjort sig gældende på tværs af de forskellige cases: for eksempel i casen om Joakim Mæhle, hvor der ikke i klassisk forstand figurerer nogen anklaget part, hvorfor der heller ikke er noget behov for genmæle. Det betyder, at vi med hensyn til genmæle henviser til $\mathrm{N}=386$, da Mæhle-dækningen udgør 24 unikke artikler, der i dette konkrete analysearbejde er trukket fra.

\section{Kodningskategorier}

Undersøgelsens resultater beror på en kvantitativ indholdsanalyse med afsæt i kodning fra tre kodere. Der er blevet kodet for manifest såvel som latent indhold. I tabel 2 opgør vi disse variable (koder fra latent indhold er markeret med fed). Forud for undersøgelsen har vi foretaget pilotkodning, som var med til at skærpe kodningskategorierne.

\begin{tabular}{|l|l|}
\hline Variable & Værdier \\
\hline Medietype & omnibus/tabloid/niche \\
\hline Format & net/print \\
\hline Genre & nyhed/opinion \\
\hline Ritzau & Ja/nej \\
\hline Rækkevidde & $\begin{array}{l}\text { Nationalt medie/Regionalt } \\
\text { eller lokalt medie/Digitalt medie/ } \\
\text { Fagblad/Magasin/Nyhedsbureau }\end{array}$ \\
\hline Genmæle_1 (er der taget kontakt?) & ja/nej/forsøgt \\
\hline Genmæle_2 (hvis ja, af mediet selv?) & ja/nej \\
\hline Vidensbidrag_1 (i alt) & $0 / 1 / 2 / 3 / 4+$ \\
\hline Vidensbidrag_2 (eksklusive) & $0 / 1 / 2 / 3 / 4+$ \\
\hline Vidensbidrag_3 (fra andre medier) & $0 / 1 / 2 / 3 / 4+$ \\
\hline Vidensbidrag_4 (fra SoMe) & $0 / 1 / 2 / 3 / 4+$ \\
\hline eW0M_1 (er der eWOM?) & ja/nej \\
\hline eWOM_2 (er der taget kontakt til eW0M-kilde?) & ja/nej/forsøgt \\
\hline SS_domæne & $\begin{array}{l}\text { politik/virksomhed/administration/ } \\
\text { medie/offentlig person }\end{array}$ \\
\hline
\end{tabular}

Tabel 2: Kodningskategorier

Kategorierne vidensbidrag_4, eWOM_1 og eWOM_2 relaterer sig alle til kilder fra sociale medier. Vidensbidrag_4 beskriver, hvor mange nye kilder (i forhold til triggerartiklen) fra sociale medier der bliver citeret i en given artikel. eWOM_1 opgør, om der indgår citater fra sociale medier, inklusive dem, der måtte indgå i triggerartik- 
len, mens eWOM_2 viser, hvorvidt der er taget kontakt til eventuelle kilder fra sociale medier. Vidensbidrag-kategorierne relaterer sig til triggerartikler og risikoen for selvreferentialitet i dækning af shitstorme, mens eWOM_1 og eWOM_2 forholder sig til verifikation og brug af kilder fra sociale medier.

Vi har foretaget en interkoderreliabilitetstest for hver af de latente kodningskategorier i 10 pct. af vores anvendte empiri $(\mathrm{N}=42)$ med tilfredsstillende resultat for alle variable (se tabel 3).

\begin{tabular}{|l|l|}
\hline Variabel & Krippendorff's Alpha \\
\hline Genmæle_1 & 1 \\
\hline Genmæle_2 & 1 \\
\hline vidensbidrag_1 & 0,94 \\
\hline vidensbidrag_2 & 0,907 \\
\hline vidensbidrag_3 & 0,804 \\
\hline vidensbidrag_4 & 0,971 \\
\hline ewom_1 & 1 \\
\hline ewom_2 & 0,971 \\
\hline SS_domæne & 1 \\
\hline
\end{tabular}

Tabel 3: Krippendorffs Alpha-koefficient for latente kodningskategorier

\section{Analyse: Tre perspektiver, der gør os klogere på, hvordan journalister dækker shitstorme}

Herfra kommer vi til at fokusere på de tre bærende spørgsmål, der skal gøre os klogere på, hvordan danske journalister har dækket 10 udvalgte shitstorme i 2019: Hvorvidt anklagede parter kommer til genmæle; i hvor høj grad der bliver investeret tid i at inddrage nye kilder eller nye vidensbidrag i det hele taget; og hvorvidt kilder er blevet kontaktet, inden de citeres i medier. Resultaterne bliver først udredt deskriptivt, herefter opsummeret i en konklusion og afslutningsvis diskuteret.

\section{Genmæle i dækningen af shitstorme}

Vores analyse viser, at journalister, der skriver om shitstorme, lader en anklaget part komme til genmæle i 61 pct. af tilfældene (se figur 1). Omvendt betyder det, at 39 pct. af artiklerne ikke har præsenteret et genmæle. 


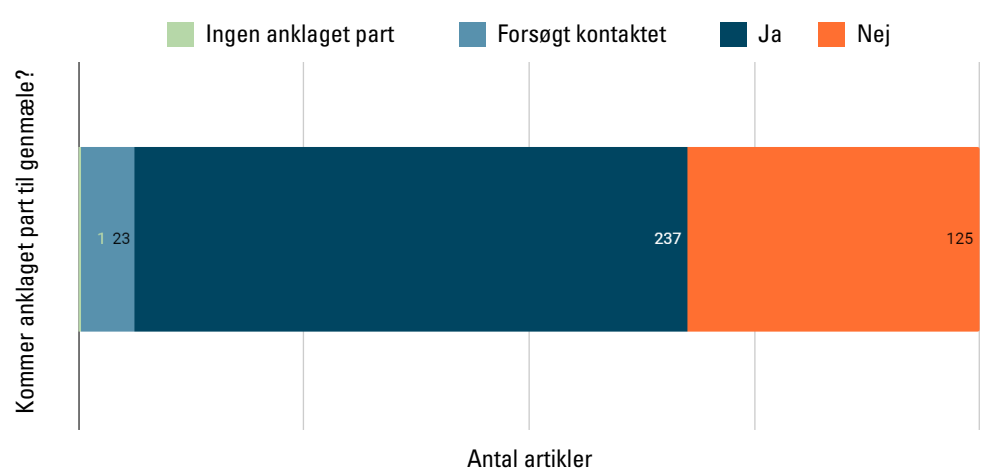

Figur 1: Fordeling af genmæle $(\mathrm{N}=386)$

Et vellykket forsøg på at lade en modpart komme til genmæle skete eksempelvis, da Ekstra Bladet dækkede sagen om Simon Simonsen (Ekstra Bladet 2019a). Her inkorporerede journalisten Simonsens opfølgende Facebook-opslag. Dertil havde journalisten kontaktet Simonsen personligt, så Simonsen med egne ord blandt andet kunne forklare, at hans Facebook-opslag "ikke er et personangreb på Joy Mogensen, men et oploeg til diskussion om kunstig befrugtning og familiestrukturer generelt" (ibid.).

Det er dog ikke uden betydning, hvilken målgruppe (og størrelsen på ditto) det enkelte medie har i forhold til at lade modparter komme til genmæle. Vi kan i figur 2 se en markant forskel i genmælepraksissen målt på de enkelte mediehuses rækkevidde i landet. Mens nationale medier præsenterer hyppigere genmæle (73 pct.), gør det sig i mindre grad gældende for de regionale og lokale medier (53 pct.), når de dækker shitstorme.

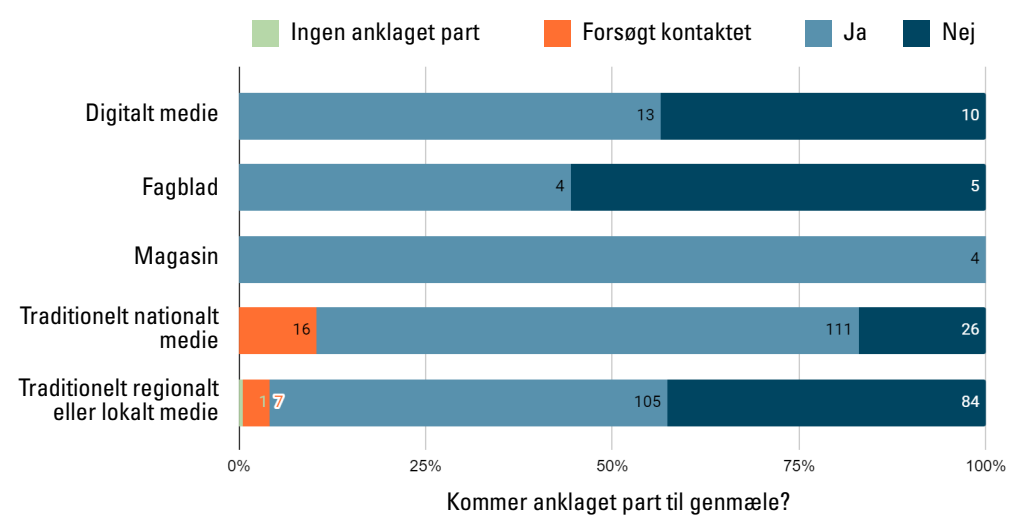

Figur 2: Fordeling af genmæle i forhold til mediernes rækkevidde $(\mathrm{N}=386)$ 


\section{Viderebringelse af nye vidensbidrag}

Vores analyse viser ydermere, at journalister mestendels bringer nye vidensbidrag i spil, når de dækker en shitstorm over flere dage. Det er vigtigt at understrege, at dette spørgsmål er undersøgt i forhold til den første artikel (dvs. triggerartiklen), der er blevet skrevet for hver case (Vasterman 2005, Elmelund-Præstekær \& Wien 2007). Den første artikel (målt på tidspunkt og dato) i en pulje af artikler om en specifik shitstorm kan altså aldrig indeholde nye kilder eller vidensbidrag - mens alle andre artikler, der følger herefter (på tværs af hele medielandskabet), bliver analyseret i forhold til den første artikel. Den første artikel danner altså sammenligningsgrundlag for efterfølgende dækninger. Ud fra denne logik har vi afdækket, at der i 78 pct. af tilfældene bliver indhentet mindst én ny kilde og/eller nye citater fra en allerede citeret kilde i forhold til triggerartiklen, når journalister dækker shitstorme (se figur 3 ).

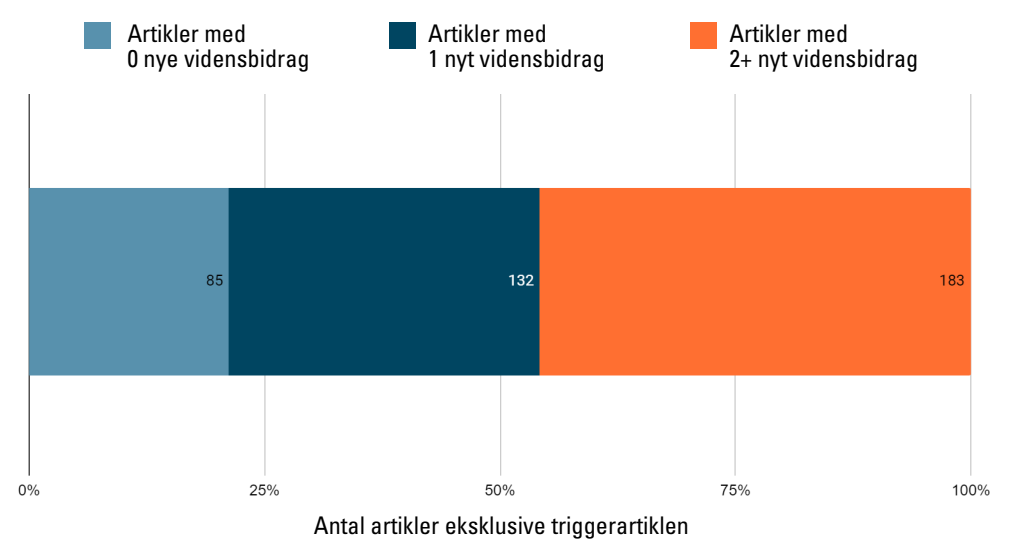

Figur 3: Overblik over antallet af nye vidensbidrag ( $N=400$, frasorteret triggerartiklerne).

To respektive dækninger af kanelsneglssagen tjener blandt andet som eksempel på dette. Under rubrikken "18-årig fyret for at spise kanelsnegl” udgiver B.T. triggerartiklen om denne shitstorm den 19. februar om aftenen (B.T. 2019). I denne er der tre kilder: Uddrag fra Mias mors Facebook-opslag, der startede harmen på Facebook, mundtlige citater fra Mia selv og et skriftligt modsvar fra Føtex' HR-chef - da det er Føtex, der er under anklage i denne sag (ibid.). 
Dagen efter dækker TV 2 Østjylland også sagen under rubrikken "Se ordene, der fik Mia fyret for at spise en kanelsnegl" (TV 2 Østjylland 2019). Heri bringer man billeder af notater fra et møde, som Mia havde med sin chef inden sin afskedigelse, der giver læseren indblik i, hvad der blev diskuteret (dokumentation). Der er et billede af et opslag, der blev hængt op i Føtex' kantine kort efter Mias fyring, der fortæller, at en medarbejder er blevet afskediget på grund af grove brud på interne regler. Der er udtalelser fra formanden i Mias fagforening samt fra Mia og Føtex' HR-chef. Selvom vi har hørt fra de to sidste kilder før, optræder de som kilder til nye vidensbidrag, fordi TV 2 Østjylland har inkorporeret en kort videobid i deres artikel, hvor vi får sat ansigt på og nye citater fra fyrede Mia og Føtex' HR-chef. På denne måde gør TV 2 Østjylland historien til deres egen (Willig 2011: 191), og de tilføjer nye vidensbidrag, der udfolder sagen yderligere og bringer den et skridt videre fra dækningen dagen forinden.

I figur 4 ser vi, at der er forskel på, hvordan man indhenter nye vidensbidrag til sit medies dækning af en shitstorm. Således er 48 pct. af de i alt 633 nye vidensbidrag blevet indhentet direkte af det respektive medie. Vidensbidragene er blevet kopieret fra andre medier i 28 pct. af tilfældene, mens 24 pct. er blevet fundet på sociale medier.

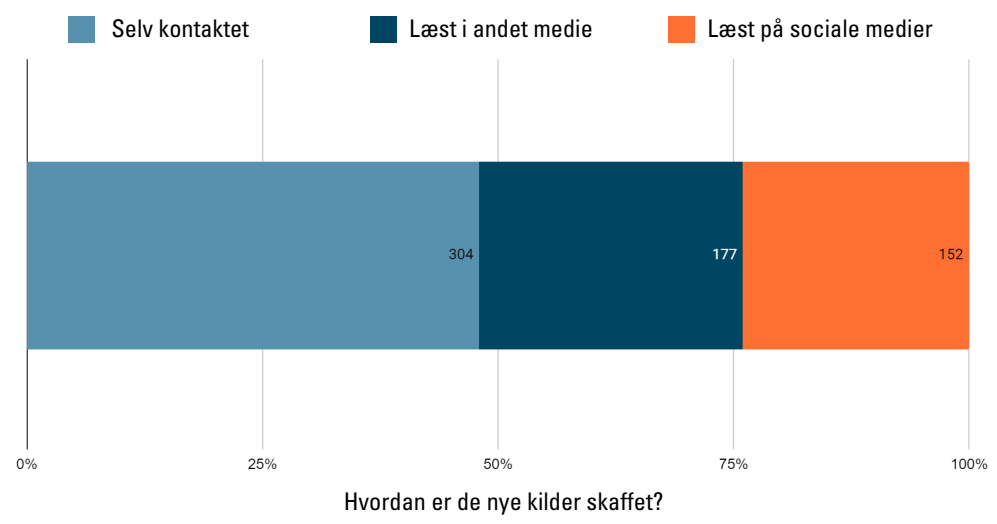

Figur 4: Antallet af nye vidensbidrag, fordelt på kildetyper, baseret på det samlede antal af kilder $(\mathrm{N}=633)$. 
Det er dog ikke uden betydning, hvem eller hvad der er anklaget i shitstormen: Vores resultater peger på, at det har en effekt på, hvilke typer af nye vidensbidrag journalisterne inddrager. Her har vi arbejdet med en skelnen mellem fire forskellige modtagere af kritik i en shitstorm. Det, der i den eksisterende forskning kaldes “domæner” (Einwiller m.fl. 2017: 1185): 1) en politiker, 2) en offentlig person, 3) en virksomhed, 4) en administration. Hver af de 10 cases har således et domæne. I figur 5 er de nye vidensbidrag opdelt i forhold til disse fire domæner. Vi kan observere, at medier oftest ringer nye eksklusive vidensbidrag hjem, når en administration er i shitstorm (60 pct. af i alt 192 vidensbidrag). Dette gjorde sig eksempelvis gældende i shitstormen mod Ringkøbing-Skjern Kommunes jobcenter, da kræftpatienten Hilde-Kristin Reed Mogensen i et Facebook-opslag offentligt kritiserede jobcenteret for ikke at respektere hendes sygdomsforløb. De lokale medier havde ofte historien på dagsordenen - eksempelvis Århus Stiftstidende, der under rubrikken "Kommune i shitstorm: Jobcenter vil sende brystkræft-opereret kvinde i jobafklaring" talte med Hilde-Kristin selv, med en folketingskandidat og formand for beskæftigelsesudvalget i Ringkøbing-Skjern Kommune samt et SFmedlem af beskæftigelsesudvalget (Århus Stiftstidende 2019).

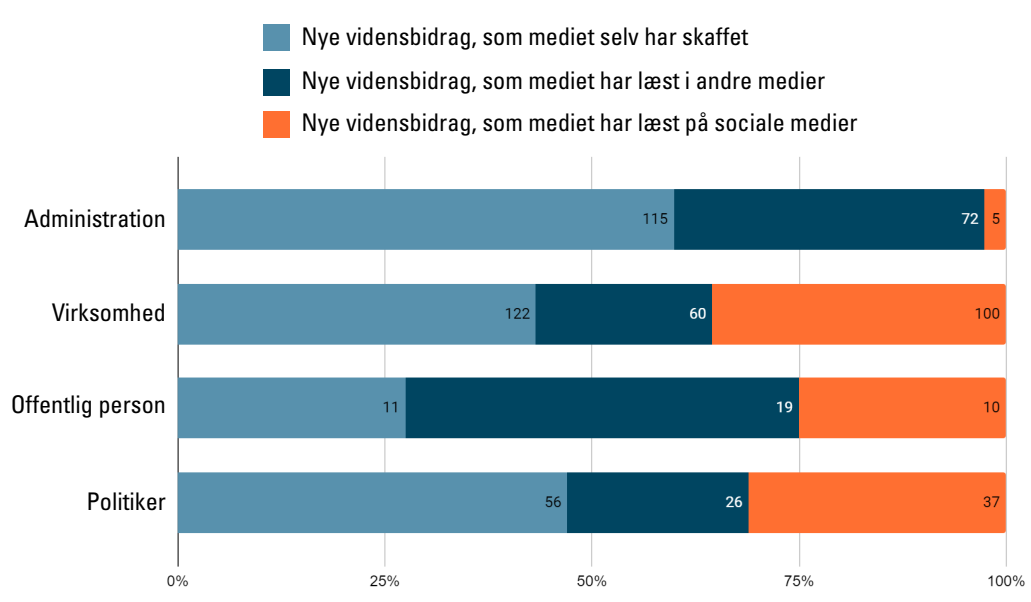

Figur 5: Her undersøger vi igen det samlede antal af kilder, fordelt på domæner og typer af vidensbidrag $(\mathrm{N}=633)$ 
Samtidig ser vi en relativt høj andel (i forhold til den samlede dækning i figur 4) af vidensbidrag kopieret fra andre medier i dækningen af shitstorme mod administrationer (37,5 pct. af $\mathrm{i}$ alt 192 nye vidensbidrag). Det er dog i dækningen af shitstorme mod offentlige personer, at vi finder flest nye vidensbidrag, som medier har læst $\mathrm{i}$ andre medier (47,5 pct. af i alt 40 nye vidensbidrag). Det gør sig eksempelvis gældende i stormen mod fodboldspiller Joakim Mæhle: Her citerer Ekstra Bladet eksempelvis Mæhle for at udtale: "Det er pisse irriterende. Jeg synes ikke, at jeg har fortjent at sidde derude. Jeg siger ikke, at jeg har fortjent at spille, men jeg har heller ikke fortjent ikke at spille $i$ hvert fald (...)" (Ekstra Bladet 2019b). Det fremgår ikke eksplicit af denne artikel, at Ekstra Bladet har læst dette citat i et andet medie - men ved at sammenholde tidspunkter for publicering af alle artikler i denne sag fandt vi, at det digitale medie Bold.dk har præcis samme citat fra Mæhle samme dag 12 timer før Ekstra Bladet (Bold.dk 2019), hvorfor man må formode, at Ekstra Bladet citerer Bold.dk.

Slutteligt fandt vi, at journalister oftest citerer kilder direkte fra sociale medier, når en virksomhed bliver kritiseret (35 pct. af i alt 282 nye vidensbidrag). Det gælder eksempelvis i sagen om varehuset POWER, hvor artikler refererer til kritik fra kunder i kommentarsporet på en af virksomhedens reklameopslag på Facebook, fordi virksomheden havde fusket med tilbudspriser op til Black Friday. Se eksempelvis Ekstra Bladets dækning, hvori der optræder citater som "Fup og svindel" og "Jeg handler aldrig hos jer igen" fra unavngivne kilder på Facebook (Ekstra Bladet 2019c).

\section{Journalisternes kontakt med kilder fra sociale medier}

Vi har i alt registreret 252 vidensbidrag fra sociale medier - det vil sige, at 252 kilder er citeret fra sociale medier. Vi kan i figur 6 se, at 68 pct. af disse kilder til nye vidensbidrag ikke er blevet kontaktet af mediet, der citerer dem. 


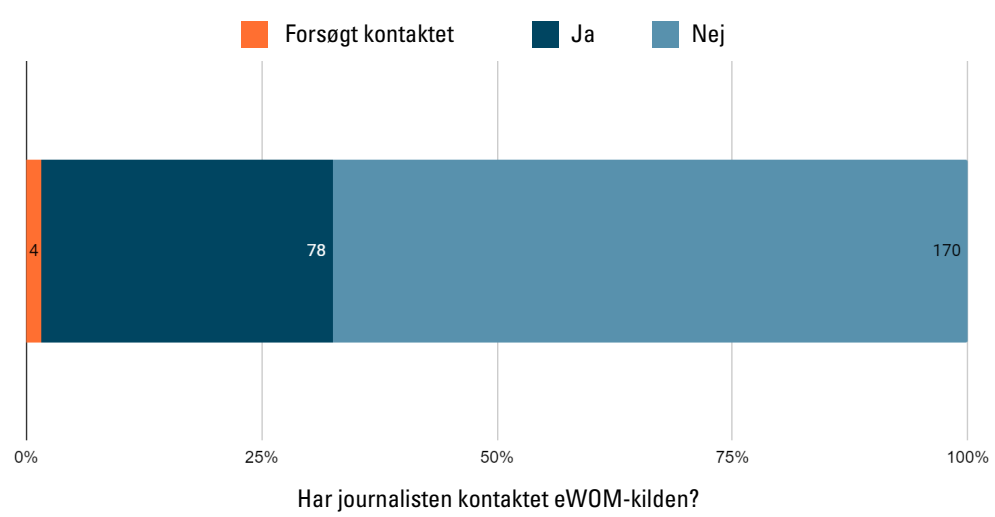

Figur 6: Generel kontakt til kilder fra sociale medier, baseret på det samlede antal af kilder fra sociale medier $(\mathrm{N}=252)$

Ydermere har vi fundet, at shitstorme, hvor kritikken er rettet mod politiske aktører, i højere grad motiverer kildekontakt: Her er der fx i Stig Grenov-sagen skabt kontakt til kilder fra sociale medier i 89 pct. af tilfældene, mens ditto gør sig gældende i 50 pct. af tilfældene i Simon Simonsen-sagen. Begge er altså med til at hæve den samlede andel til 32 pct.

\section{Opsamling}

Opsamlingen på analysen er inddelt i tre underafsnit svarende til de tre analyser: genmæle, nye vidensbidrag og journalisters kontakt til kilder fra sociale medier.

\section{Genmæle}

Den overordnede konklusion fra analysen om genmæle er, at 61 pct. af de unikke nyhedsartikler (på nær artikler under Joakim Mæhle-sagen) fremsætter genmæle fra en anklaget part. Det betyder samtidig, at 39 pct. af artiklerne ikke fremsætter genmæle fra en anklaget part. Ud fra et journalistisk ideal om, at præsentationen af genmæle er vigtigt i sig selv, kan man med afsæt i disse resultater kritisere danske journalisters manglende fokus på netop dette. Denne diskussion vil blive udfoldet i det kommende diskussionsafsnit. 
Udover den overordnede konklusion peger vores resultater på, at der i højere grad bliver præsenteret genmæle af nationale medier end regionale medier. Tager man udgangspunkt i sagen om Simon Simonsen, bliver dette da også tydeligt, hvis man holder en landsdækkende avis som Ekstra Bladet op imod regionalmediet TV 2 Lorry. Omkring et døgn efter Ekstra Bladets overskrift har Lorry også sagen på dagsordenen - men til forskel fra Ekstra Bladet bringer Lorry en artikel uden nogen form for modsvar fra Simonsen selv (TV 2 Lorry 2019), og dét på trods af, at Lorry har mulighed for at citere genmælet fra Ekstra Bladet og/eller at søge mod Facebook, hvor Simonsen selv har givet svar på anklage til den bredere offentlighed, sådan som Ekstra Bladet gjorde (Ekstra Bladet 2019a).

\section{Nye vidensbidrag}

Den overordnede konklusion, som vi kan drage fra analysen om nye vidensbidrag, er, at 78 pct. af unikke nyhedshistorier (foruden triggerartikler) viderebringer nye oplysninger i den pågældende sag. En yderligere granskning viser, at journalister i højere grad anvender citater fra en eksklusiv kilde, de selv har kontaktet (48 pct. af tilfældene), mens de i mindre grad citerer udsagn fra kilder, de har læst i andre etablerede medier (28 pct. af tilfældene). Hermed har de fundet færrest nye kilder (24 pct. af tilfældene) via opslag eller kommentarer på de sociale medier.

Det er dog ikke uden betydning, hvem eller hvad shitstormen drejer sig om - vores resultater peger nemlig på, at det har en effekt på, hvordan journalister anvender kilder. Således har vi fastslået, at andelen af nye vidensbidrag er størst, når det er en (kommunal) administration, der modtager kritik i shitstormen - 60 pct. af i alt 192 nye vidensbidrag er eksklusive, hvad angår administrationsdomænet.

Den største andel af kilder læst og citeret i andre medier findes imidlertid også i dækningen af shitstorme mod administrationer, hvor 37,5 pct. af de 192 nye vidensbidrag er hentet fra andre medier. Slutteligt fandt vi, at journalister oftest citerer kilder direkte fra sociale medier, når det er en virksomhed, der bliver kritiseret. Her er det 35 pct. af i alt 282 nye vidensbidrag, der er hentet direkte fra sociale medier. Dette kan ses som udtryk for, at en eller flere sagsori- 
enterede offentligheder får forstærket deres stemmer i shistorme på sociale medier og senere via traditionelle medier.

\section{Journalisters kontakt til kilder fra sociale medier}

Vi kan konkludere, at journalister oftest ikke tager kontakt til kilder fra sociale medier, inden de vælger at bruge deres udsagn i en artikel. Der er taget kontakt i 32 pct. af de 252 tilfælde, mens det modsatte sker i 68 pct. af tilfældene. Vi observerer imidlertid to outliers: Stig Grenov-sagen (kontakt i 89 pct. af tilfældene) og Simon Simonsensagen (kontakt i 50 pct. af tilfældene), hvilket vi ser to mulige årsager til: Dels er politikere historisk set blevet mere og mere tilgængelige for pressen som en del af medialiseringen af politisk kommunikation (Blach-Ørsten 2016, Hjarvard 2008), dels bestod en stor del af den anvendte eWOM fra enten Grenov eller Simonsen selv. Da det også var dem, der stod på mål for anklager fra den brede offentlighed, kan man forestille sig, at det i højere grad har foranlediget journalisterne til at tale med kilden jf. idealet om at tale med den anklagede part, som vi har påvist følges i størstedelen af artiklerne.

\section{Diskussion af resultater og kodningskategorier}

Vi vil herunder diskutere vores resultater og vores kodningskategoriers videnskabelige anvendelighed i studiet af journalistisk dækning af shitstorme. Herunder vil vi granske vores metodiske fremgang, som også her er struktureret efter vores tre analysedele.

\section{Genmæle}

Resultaterne fra analysen om genmæle peger på et problem med den journalistiske dækning af shitstorme, idet blot 61 pct. af artiklerne indeholder genmæle. Denne kritik tager dog ikke højde for de små nuancer i læseoplevelser - noget, som Infomedia ikke tager højde for. Et eksempel på en sådan nuance er i B.T.s dækning af sagen om Simon Simonsen. Den 7. maj 2019 udgiver B.T. to artikler på samme side i deres fysiske avis, der begge handler om den verserende sag$^{2}$ : en artikel, hvor journalisten taler med den anklagede part (Simonsen), og en artikel, hvor journalisten rådfører sig med en 
ekspert for at forstå, hvorfor Simonsens Facebook-opslag udviklede sig til en shitstorm. Læser man disse to artikler på Infomedia, får man oplevelsen af, at det er to helt separate nyhedsartikler. Derfor får man som læser på Infomedia en læseoplevelse, hvor der er én artikel, hvor anklaget part kommer til genmæle - mens den anden ikke hører anklaget part. Det medfører to forskellige kodninger, når det handler om spørgsmålet om genmæle. Det er dog ikke den oplevelse, en læser vil få ved at sidde med avisen fysisk $\mathrm{i}$ hånden: Her forstår man tværtimod de to artikler i relief til hinanden, hvorfor der altså ikke er mangel på genmæle. Humlen ved dette er, at journalistisk output ofte er meget mere dynamisk og kreativt, end hvad indholdsanalyse tillader at observere og beskrive med hensyn til idealet om genmæle. Dermed ikke sagt, at manglende genmæle i sig selv er uproblematisk, men der eksisterer nuancer, som vi erkender, at vi ikke får beskrevet via vores indholdsanalyse.

Samtidig kan man rejse en overordnet diskussion om genmælets betydning for journalistisk kvalitet. For er det nødvendigvis dårlig journalistik, når genmæle mangler? Det umiddelbare svar på dette er nej. Genmæle er nemlig ikke et intrinsisk gode i sig selv (Kovach \& Rosenstiel 2001: 77), men har snarere instrumentel værdi i forhold til opnåelse af god journalistik. Sagt på en anden måde sikrer genmæle i sig selv ikke høj kvalitet, men kan tages i brug af journalister for at nærme sig en mere fair portrættering af sagen - hvilket i sidste ende kan løfte kvaliteten af artiklen.

Genmæle er i en sådan betragtning relevant som et normativt ideal for journalistisk praksis, men det er vanskeligt at operationalisere konceptet som en relevant kodningskategori i en indholdsanalyse.

\section{Nye vidensbidrag}

Til gengæld har kodningskategorierne under nye vidensbidrag vist sig at være brugbare og interessante i forhold til at danne overblik over et bestemt nyhedsflows informationsudvikling. I vores arbejde med kodningskategorien har vi imidlertid bestemt et startpunkt (altså triggerartiklen), hvilket udgør sammenligningsgrundlaget for den resterende empiri. Dette medfører, at vi ikke kan bestemme informationsudviklingen fra artikel til artikel, men snarere fra triggerartikel til artikel. På den måde kan vi altså sige noget om den totale udvikling fra den første dato til sidste dato, men kan ikke sige 
noget brugbart om bestemte perioder i nyhedsdækningen i forhold til informationsudviklingen. Man kan for eksempel tænke sig, hvordan visse perioder i en shitstorm er informationsmæssige 'lavkonjunkturer', mens andre perioder er 'højkonjunkturer'. Disse nuancer begriber vores anvendelse af kodningskategorien ikke, og fremtidige studier, der påtænker at anvende denne, kan med fordel overveje, om kategorien skal udvikles, således at de periodevise udsving i informationsudviklingen kan bestemmes.

Konceptualiseringen af kategorien nye vidensbidrag finder vi særdeles interessant, idet journalistikken (se fx American Press Institute 2013) og medieforskningen (se fx Willig 2011: 165ff) generelt lægger stor vægt på forestillinger om eksklusivitet, originalitet og selvstændigt arbejde. Vi er dog ikke stødt på nogen kvantitativ metode til empirisk at undersøge disse koncepter, og derfor introducerer vi altså denne kodningskategori.

\section{Kilder fra sociale medier}

I et kritisk perspektiv kan resultaterne fra analysen om sociale mediekilder tolkes som et udtryk for en form for journalistisk dovenskab: 68 pct. af de 252 undersøgte vidensbidrag fra sociale medier er viderebragt, uden de givne journalister har taget eller forsøgt at tage kontakt til kilderne bag. Det vidner altså om en redaktionel interesse i at dække historien, som dog ikke er stor nok til, at der prioriteres ressourcer til at kontakte kilder fra sociale medier.

Herudover har vi kunnet observere, at journalisters brug af kilder fra sociale medier både tilskynder gode og dårlige praksisser. På den ene side gemmer der sig et demokratisk potentiale i den journalistiske anvendelse af kilder fra sociale medier, da disse kilder kan fordre, at svage menneskers stemmer bliver styrket i samfundsdebatten (Rønlev 2018: 49f). Videre kan man argumentere for, at vidensbidrag fra sociale medier er legitime stemmer i større samfundsdebatter fra sagsorienterede offentligheder, der er nødvendige at inddrage i nyhedsdækning, hvis man vil give et dækkende billede af de forskellige verdenssyn, der eksisterer og udvikler sig i et samfund (Birkbak 2018: 57).

På den anden side hviler der en særlig opgave på mediernes skuldre set i forhold til, hvordan de præsenterer den givne sag og bruger kilder på sociale medier som vidnesbyrd for, hvordan flertal- 
lets holdning er imod den eller dem, der bliver kritiseret i shitstormen. Vi har i vores analyse set eksempler på, hvordan journalister kan vinkle en rubrik eller underrubrik så skarpt, at det virker misvisende for sagens egentlige indhold: Et eksempel, som vi tidligere har berørt, er sagen om Simon Simonsen, hvor en journalist valgte at fremhæve en række kritiske kommentarer fra Facebook for dermed at skabe belæg for formuleringen "Der er udbrudt brand i Simonsens Facebook-profil" (Ekstra Bladet 2019a) - selvom flere brugere i kommentarfeltet faktisk udtrykker deres enighed med Simonsens udtalelser. ${ }^{3}$ Den journalistiske forenkling og til tider misvisende eller dramatiserede repræsentation af engagementet på sociale medier er også tidligere blevet problematiseret for at sætte en bestemt offentlig opinion på dagsordenen, selvom der i de givne kommentarspor og reaktionsopgørelser også figurerer opponerende meninger (Rønlev 2018: 67ff). Derfor kan journalisters indblanding nemt forstærke problemet ud af proportioner, så læserne kan få den opfattelse, at problemet - og arrigskaben over problemet - er meget større, end hvad det i virkeligheden er. Det er dog vigtigt at huske på, at der ikke står noget eksplicit i Pressenævnets vejledende regler om brugen af kilder fra sociale medier - og derfor er journalister i langt højere grad overladt til individuel refleksion over en retfærdig og hensynsfuld praksis, der lige nu ikke er formaliseret, men mest styret af ens eget etiske kompas og journalistiske mavefornemmelse (se fx Schultz 2007: 191f). Dette er en tidligere beskrevet omstændighed for journalister, at etiske retningslinjer i praksis udgår fra en blanding af Pressenævnet, mediernes interne regelsæt og journalistens fortolkning af disse (Blach-Ørsten m.fl. 2015).

\section{NOTER}

1 Vi har anvendt det digitale søgeredskab Infomedia til at undersøge dette. I 2009 blev der i alt produceret 710 artikler, mens der i 2019 blev produceret 4.864 af ditto.

2 Det er ikke muligt at henvise til de to nævnte artikler, da det er artikler i fysisk papirformat. For at finde artiklerne kan man tilgå Infomedia og bruge søgestrengen 'joy mogensen' AND 'simon simonsen' AND '*donor*' via ekspertfunktionen og indskrænke søgningen til den 7. maj 2019.

3 De aktuelle reaktioner på Simonsens indlæg kan findes på hans offentlige Facebook-profil: https://www.facebook.com/simonsjsimonsen/ 


\section{REFERENCER}

American Press Institute (2013). “Journalism as a discipline of verification” af W. Dean. Set 01-09-2020 på https://www.americanpressinstitute.org/ journalism-essentials/verification-accuracy/journalism-discipline-verification/

B.T. (2019). "18-årig fyret for at spise kanelsnegl” af J. Juhler den 19. februar 2019. Set 01-09-2020 på www.bt.dk/erhverv/18-aarig-fyret-for-at-spisekanelsnegl

Birkbak, A. (2018). Shitstorms, bobler eller sagsorienterede offentligheder? Digitale metoder og kontroverser på sociale medier. Dansk Sociologi 1(29), 37-61. doi: 10.22439/dansoc.v29i1.5723

Blach-Ørsten, M. (2011). Politiske skandaler i danske medier i 1989-2010. Tidsskriftet POLITIK 3(14), 7-17. doi: https://doi.org/10.7146/politik. v14i3.27485

Blach-Ørsten, M. (2016). Politikkens medialisering: Et ny-institutionelt perspektiv. I Hjarvard, S. (red.), Medialisering: Mediernes rolle i social og kulturel forandring (s. 185-216). Hans Reitzel.

Blach-Ørsten, M., Møller Hartley, J., Flensburg, S. \& Bendix Olsen, M. (2015). Specialrapport Medieetik. Center for Nyhedsforskning, CBIT, Roskilde Universitet. https://mediernesudvikling.slks.dk/2015/specialrapporter/ medieetik/

Bold.dk (2019). "Irriteret Mæhle: Har ikke fortjent bænkplads" den 18. juni 2019. Set 01-09-2020 på www.bold.dk/fodbold/nyheder/irriteret-maehlehar-ikke-fortjent-baenkplads/.

Boydstun, A. E., Hardy, A. \& Walgrave, S. (2014). Media Storm versus Non-Coverage Storm. Political Communication 31(4), 509-531. doi: 10.1080/10584609.2013.875967

Danmarks Statistik (2020). It-anvendelse $i$ befolkningen 2019. Fundet 20-11-2020 på https://www.dst.dk/Site/Dst/Udgivelser/GetPubFile. aspx?id=29449\&sid=itbef2019.

Einwiller, S., Viererbl, B. \& Himmelreich, S. (2017). Journalists' Coverage of Online Firestorms in German-Language News Media. Journalism Practice 11(9), 1178-1197. doi: 10.1080/17512786.2016.1229578

Ekstra Bladet (2019a). "Partifælle om donor-gravid borgmester: Selvcentreret og egoistisk” af M. Nørgaard den 1. maj 2019. Set 01-09-2020 på www. ekstrabladet.dk/nyheder/politik/danskpolitik/partifaelle-om-donor-gravid-borgmester-selvcentreret-og-egoistisk/7615844

Ekstra Bladet (2019b). "Fornærmet dansk EM-talent i stort knæfald: - Undskyld” af K. Egelund den 18. juni 2019. Set 01-09-2020 på www.ekstrabla- 
det.dk/sport/fodbold/fornaermet-dansk-em-talent-i-stort-knaefaldundskyld/7677939

Ekstra Bladet (2019c). "POWER i kæmpe shitstorm før black friday: 'Fup og svindel'” af N. Nedergaard den 28. november 2019. Set 01-09-2020 www. ekstrabladet.dk/nyheder/samfund/power-i-kaempe-shitstorm-foerblack-friday-fup-og-svindel/7893514

Elmelund-Præstekær, C. \& Wien, C. (2007). Mediestormens magt. Om mediestorme på aldreområdet og deres indflydelse på aldrepolitikken. 1. udgave. Syddansk Universitetsforlag.

Eskjær, M. F. \& Helles, R. (2015). Kvantitativ Indholdsanalyse. Samfundslitteratur.

Galtung, J. \& Holmboe Ruge, M. (1965). The Structure of Foreign News - The Presentation of the Congo, Cuba and Cyprus Crises in Four Norwegian Newspapers. Journal of Peace Research 2(1), 64-90. doi: 10.1177/002234336500200104

Hammarlin, M.(2019). Media scandals, rumour and gossip:Astudy with an ear closetotheground.InternationalJournalofCulturalStudies.LundUniversity. doi: 10.1177/1367877919872511

Herhausen, D., Ludwig, S., Grewal, D., Wulf, J. \& Schoegel, M. (2019). Detecting, Preventing, and Mitigating Online Firestorms in Brand Communities. Journal of Marketing 83(3), 1-21. doi: 10.1177/0022242918822300

Hjarvard, S. (2008): En verden af medier: Medialiseringen af politik, sprog, religion og leg. Samfundslitteratur.

Jensen, J. L. (2020). Sociale medier spiller en stor rolle for den politiske dagsorden - men en mindre rolle i den demokratiske debat. Media Journal. Danmarks Medie- og Journalisthøjskole.

Jensens Bøfhus (2015): Årsrapport for 2014. Set 20-11-2020 på https://regnskaber.cvrapi.dk/83521231/ZG9rdW1lbnRsYWdlcjovLzAzLzhmLzg3LzdiL2IyLzRlYTgtNDJkMylhZGZjLTlmMDk3YTYyYjQzMg.pdf

Johnen, M., Jungblut, M. \& Ziegele, M. (2018). The digital outcry: What incites participation behavior in an online firestorm? New Media \& Society 20(9), 3140-3160. doi: 10.1177/1461444817741883

Kepplinger, H. M. \& Habermeier, J. (1995). The Impact of Key Events on the Presentation of Reality. European Journal of Communication 10(3), 371390. doi: 10.1177/0267323195010003004

Kovach, B. \& Rosenstiel, T. (2001). The elements of journalism: What newspeople should know and the public should expect. Crown Publishers.

Lund, A. B. (red.) (2000). Først med det sidste - en nyhedsuge i Danmark. Forlaget Ajour. 
Paulussen, S. \& Harder, R. A. (2014). Social Media References in Newspapers - Facebook, Twitter and YouTube as sources in newspaper journalism. Journalism Practice 8(5), 542-551. doi: https://doi.org/10.1080/17512786 .2014 .894327

Pfeffer, J., Zorbach, T. \& Carley, K. M. (2014). Understanding online firestorms: Negative word-of-mouth dynamics in social media networks. Journal of Marketing Communications 20(1-2), 117-128. doi: 10.1080/13527266.2013.797778

Pressenævnet A: “Vejledning om genmæle”. Set 01-06-2020 på www.pressenaevnet. dk/vejledning-om-genmaele/

Pressenævnet B: "Vejledning om god presseskik". Set 01-06-2020 på www. pressenaevnet.dk/god-presseskik/

Rønlev, R. (2018). Brølet i kommentarsporet: Journalisters formidling af den offentlige opinion på politiken.dk. Journalistica 12(1), 48-77. doi: https:// doi.org/10.7146/journalistica.v12i1.105541

Rauschnabel, P., Kammerlander, N. \& Ivens, B. (2016). Collaborative Brand Attacks in Social Media: Exploring the Antecedents, Characteristics, and Consequences of a New Form of Brand Crises. The Journal of Marketing Theory and Practice 24(4), 381-410. doi: 10.1080/10696679.2016.1205452

Schultz, I. (2007). The Journalistic Gut Feeling: Journalistic doxa, news habitus and orthodox news values. Journalism Practice 1(2), 190-207. doi: https://doi.org/10.1080/17512780701275507

Skovsgaard, M., van Dalen, A. \& Bisgaard, K. (2018). Et ædelt fag under stigende pres? Udviklingen i journalisternes professionelle idealer og deres opfattelser af det daglige arbejde som journalist 2009-2015. Journalistica 12(1), 4-26. doi: 10.7146/journalistica.v12i1.105539

Thompson, J. B. (2002). Den politiske skandale: Magt og synlighed i mediealderen. Hans Reitzels Forlag.

TV 2 (2019). "Sagsbehandlere blev lovet isbar for at nedbringe antallet af sygemeldte borgere" af E. Færch og N. Lykke Møller den 1. juni 2019. Set 01-09-2020 på https://nyheder.tv2.dk/samfund/2019-07-01-sagsbehandlere-blev-lovet-isbar-for-at-nedbringe-antallet-af-sygemeldte-borgere

TV 2 Østjylland (2019): "Se ordene, der fik Mia fyret for at spise en kanelsnegl” af M. Nørgaard den 20. februar 2019. Set 01-09-2020 på https:// www.tv2ostjylland.dk/syddjurs/se-ordene-der-fik-mia-fyret-spise-enkanelsnegl

Vasterman, P. L. M. (2005). Media-Hype: Self-Reinforcing News Waves, Journalistic Standards and the Construction of Social Problems. European Journal of Communication 20(4), 508-530. doi: https://doi. 
org/10.1177/0267323105058254

Ward, S. J. A. (2019). Journalism Ethics. I K. Wahl-Jorgensen \& Hanitzsch. T. (red.), The Handbook of Journalism Studies (s. 307-323), 2. udgave. Routledge.

Willig, I. (2011). Solo, selvjustits og egenhistorier: Medspillende modspillere. I. Willig (red.), Bag nyhederne: Voerdier, idealer og praksis (s. 161-191), 2. udgave. Samfundslitteratur.

Århus Stiftstidende (2019). "Kommune i shitstorm: Jobcenter vil sende brystkræft-opereret kvinde i jobafklaring" af L. Kryger den 30. maj 2019. Set 01-09-2020 på www.stiften.dk/artikel/kommune-i-shitstorm-jobcenter-vil-sende-brystkr\%C3\%A6ft-opereret-kvinde-i-jobafklaring

\section{EMIL OLSEN}

Cand.comm. i Journalistik \& Globale Studier

Roskilde Universitet

emil.vro@gmail.com

\section{NICKLAS ANDERSEN}

Cand.comm. i Journalistik \& Filosofi

Roskilde Universitet

nicklasbunck@gmail.com

\section{IDA ZACHRAU}

Cand.comm i Journalistik \& Kommunikation

Roskilde Universitet

iza.minmail@gmail.com 